\title{
Yahweh Instructs Job on the Character of the Creation (Job 38:1-39:30)
}

\section{Yahweh poucza Hioba o charakterze stworzenia (Hi 38,1-39,30)}

Key words: Creation; the Book of Job; the first speech of Jahwe; ecology in the Bible.

Słowa klucze: stworzenie; Księga Hioba; pierwsza mowa Jahwe; ekologia w Biblii.

\begin{abstract}
The article is focusing on the first speech of Yahweh - out of the whirlwind - seeking to consider a reorientation presented in the speech (38:1-39:30). Yahweh's description of the world gives insights that provide a guide for humans to relate to the earth, not as dominators, but as custodians. This fact bears consequences not only for Job and his audience, but is also relevant for the contemporary man.
\end{abstract}

Streszczenie. Artykuł podejmuje kwestie związane z pierwszą mową Jahwe $(38,1-$ 39,30). Autor stawia sobie za cel pokazanie pewnej reorientacji zawartej w tej mowie, która - ku zaskoczeniu czytelnika - prawie w całości poświęcona jest dziełu stworzenia. Opis świata zaproponowany przez Jahwe w tym tekście dostarcza treści, które z kolei składają się na przewodnik dla ludzkości, która winna odnosić się do ziemi, nie z pozycji władców, ale stróżów. Takie postawienie sprawy domagało się zajęcia postawy przez Hioba i jemu współczesnych, ale jest również wciąż w mocy w świecie współczesnym.

7 he Book of Job presents interpreters with numerous challenges. A major 1 one is discerning the significance of the Yahweh speeches (38:1-41:24), especially since Yahweh rambles on about the creation in a way that seems to ignore Job's demand that his case be heard by the heavenly court. Audiences likewise are keenly disappointed because the dramatic action has led them to expect Yahweh to account for the suffering of the upright. In fact, in the twentieth century several interpreters judged the Yahweh speeches to be nothing more than a bluster of words. However, in the last three decades several scholars have made progress in bringing to light contributions that these speeches make to the book's teaching. The poet gives several signals that Yahweh's speeches present Job a new orientation on the character of the world's structure and its op- 
eration: the use of God's name, Yahweh, the length of the speeches, the elegance of the poetry, ${ }^{1}$ and God's appearing in a powerful storm. ${ }^{2}$ This essay seeks to consider that reorientation presented in Yahweh's first speech (38:1-39:30).

\section{Yahweh's Instructing Job on the World's Structure and Its Ecology}

At the outset Yahweh addresses Job with a question that indicates that he has spoken without adequate insight. He then commands Job to gird his loins like a man. By addressing him as a strong or noble man (גבר), i.e., a prominent leader in the community, Yahweh shows genuine respect for Job as he invites him to settle the lawsuit that he has filed by a verbal wresting match. ${ }^{3}$ In antiquity two of the ways for settling a legal dispute were by a disputation or a wrestling match (cf. 9:3-4). In a disputation the party who reduces the other to silence was the winner. By inviting Job to take this approach, Yahweh turns the plot from a legal dispute back to a disputation. Since Job raises no objection, Yahweh continues by putting to his troubled servant a host of questions. He takes this approach not to browbeat Job, but to engage his thinking as he endeavors to reestablish rapprochement between them. ${ }^{4}$ That is, Yahweh is seeking to change Job's perspective about his plight in order to overcome the huge rift that has developed between them. He realizes that the alienation Job feels could not be overcome by simply declaring Job to be innocence. Only by changing Job's perspective on the way he manages the world will Job again have full confidence in Yahweh, the confidence necessary for him to once again serve his community effectively (see Job 29). ${ }^{5}$

1 Alter states that the poetry of the Yahweh speeches is more elegant than the superb poetry of the other speakers (The Wisdom Books, 158).

2 See Luc, "Storm and the Message of Job." He focuses on the motif of "storm" in the Book of Job. Although Job feared that God would crush him with a storm (9:17), God appeared in a storm and addressed Job with respect. In the epilogue Job's stating that he has seen God refers to the storm in which God appeared. $131-36$.

3 Cf. Cyrus H. Gordon, "Belt Wrestling in the Bible World," HUCA 23 (1950-51):

4 Fox ("Job 38 and God's Rhetoric," 58) points out that the type of rhetorical questions God puts to Job "bind speaker and auditor closer together while making the auditor accept the speaker's claims out of his own consciousness rather than having the information imposed on him for the outside."

5 It is important to keep in mind that Yahweh is also speaking to the interlocutors, whom, it may be imagined, are overhearing Yahweh's words, especially since they have supported their errant counsel to Job with illustrations from nature. 
In his first speech Yahweh addresses three topics: 1) the core structure of the world: its foundation, the sea, the dawn, and its extremities $(38: 4-24),{ }^{6}$ 2 ) the systems that support the world, particularly those that provide it water (38:25-38), and 3) the care Yahweh extends to the animals that inhabit the wilderness (38:39-39:30). His goal is to convince Job that "everything that exists gives evidence of forethought, planning, and wisdom."7 Furthermore, by describing the way he has made and sustains the created order, Yahweh is countering Job's bitter charge that God's rule is arbitrary and beyond accountability (9:5-12). In fact, Job's harsh complaints have cast a dark shadow over God's management of the world order. Thus Yahweh focuses on creation in responding to Job. Yahweh begins with the way he founded the earth to counter Job's attack on the created order in desiring to curse the day of his birth (ch 3 ). He longed for the most skilled sorcerer to perform a spell that would remove that day from the world order so that his existence would be completely annihilated.

Yahweh begins by emphasizing that he built the world according to the blueprints he had skillfully drawn (38:4-15). "Blueprints" symbolizes that he constructed the world as a complex edifice for housing a myriad of life forms. The magnificent world, given its magnitude, complexity and beauty, bears witness to Yahweh's superior wisdom - in the wisdom tradition one of the skills that Woman Wisdom bestows is the ability to design and build a mansion for entertaining and instructing guests (Prov 14:1a; 9:1). During the construction of the foundation Yahweh periodically measured the work completed, making sure that it conformed to the blueprints. As the heavenly hosts watching the construction were amazed. They responded by holding a ceremony to celebrate the laying of earth's cornerstone at which the morning stars sang joyfully and the sons of God gave forth exuberant shouts in anticipation of the a majestic edifice being built.

On this secure foundation Yahweh placed the turbulent, majestic sea to be its dominant occupant. ${ }^{8}$ Yahweh describes the sea's origin by using the imagery of a woman's giving birth. As the sea burst from the cosmic womb, Yahweh, like

6 That Yahweh focuses his first speech on creation is not surprising given the numerous references to creation present throughout the dialogue and the Elihu speeches.

7 Clines, Job 38-42, 1089.

8 van Wolde ("Dialogue between Job 28 and Job 38," 375-77) argues that God's constructing the foundation and bringing forth the sea is one creative act. She bases this position both on the Hebrew syntax and Mesopotamian accounts. In those accounts earth's surface was viewed as circular and the ocean, considered to be cosmic, "encircled the continental portion of the earth's surface" (373). She draws heavily on the work of W. Horowitz, Mesopotamian Cosmic Geography (Winona Lake, IN: Eisenbrauns, 1998). 
a midwife, proudly nurtured the newborn by wrapping it in blankets of clouds. ${ }^{9}$ Aware that the sea had the ability of raging so furiously that its waves could cause massive destruction across vast land areas, Yahweh restricted the range of its impact by enclosing it behind bars and doors. Since these barriers are insufficient to contain the sea when aroused, Yahweh placed it under a divine decree ( $)$, which functions as a law. ${ }^{10}$ In these two pictures Yahweh highlights the fact that the world is securely founded and the forces that constitute its environment are dynamic. Moreover, Yahweh is confronting Job's wish that the day of his birth be removed from the cosmic calendar. Job's wish is not only impossible, but it fails to consider the intricate design and majestic beauty of the world God had made. Yahweh is also responding to Job's complaint that Yahweh is treating him like the sea or the sea monster (7:11). If that were the case, Yahweh would be treating him like a newborn infant, not as a fierce adversary, as Job imagines.

Yahweh proceeds by pointing to the dawn's vital role in curtailing the activity of the wicked. Every morning the dawn rises, always on schedule. Its colorful light slowly gives shape to the dark. Like a matron's grabbing a tablecloth and shaking off the crumbs, it drives evildoers into hiding. With this picture God provides evidence that he has placed forces in the world's structure that curb the activities of the wicked. Also the slowly rising dawn produces a panorama of color across the horizon and on the landscape. The amazing display captivates humans, filling them with exuberant joy. Beauty is an important aspect of the way Yahweh has structured the created order, for it provides humans great pleasure and functions as an antidote to the troubled minds of those who suffer. ${ }^{11}$ Also by describing the dawn's role after the birth of the sea Yahweh

9 Alter, The Wisdom Books, 159, notes that the numerous birth images in this speech signals that God is making a direct response to Job's wish that he had never been born (Job 3).

10 Clines, Job 38-42, 1102.

11 O'Connor, "Wild, Raging Creativity," 171-79, argues that Yahweh's speeches are about the great beauty of the creation, God, and Job. She draws on the work of Elaine Scarry in On Beauty and Being Just (Princeton: Princeton University Press, 1999): 50-58). O'Connor describes the power of beauty: "beauty focuses one outward... creates a sharpened attentiveness... 'incites' creativity in the replication of that which is beautify" (178). It also motivates a person to become open to extending care to others.

Beauty, an important theme in Yahweh's speech, provides solace to those who are suffering and inspires them to look beyond their plight to the glories and wonders of the creation. Having this power, beauty challenges a strict interpretation of retribution. Since doctrine has no mechanism for factoring in the consolation beauty provides a person who is suffering, it is unable to guide a person with latitude in applying that doctrine to real life situations. 
shows that these two great natural forces have diametrically different characteristics: the sea is notoriously unruly but the sun's rising always takes place precisely at the time set.

After questioning Job about the dawn that rises in the east, Yahweh seques into asking Job about earth's extremities: the recesses of the deep, where springs feed the sea and the gates of death guard the realm of deep darkness (38:16-18), the dwelling place of light and darkness, the distant east and far west (38:1921 ), and the heights of the heavens, the location of the storehouses of snow and hail (38:22-24). In asking Job if he had visited these recesses, Yahweh is referencing the ancient belief that anyone who has visited the world's extremities has comprehensive insight into the way the earth operates. ${ }^{12}$ Remaining silent Job concedes that he has no knowledge of these regions. With these questions Yahweh implies that, having searched these recesses, they are under his complete control.

In the next four vignettes Yahweh questions Job about the ways the earth receives water for supporting its vegetation and animals: a torrential thunderstorm (38:25-27), distinctive forms of water (38:28-30), four constellations (38:31-33), and clouds that transport water to distant places (38:34-38). These vignettes are connected also by terms related to way: channel (v 25a), way (v 25b), chains (v 31a), cords (v 31b), and ordinances or rule (v 33). God has put these paths which are invisible to humans in place so that most regions of the earth receive rain.

In the first vignette of this series Yahweh stresses that he has structured the world so that the desert and desolate lands where no humans dwell receive heavy rains. Even though humans do not live there, these regions need water so that the land blossoms, providing grass for the wild animals (39:8). In showing his care for all regions of the earth, even those that humans spurn, especially in antiquity. Yahweh is providing evidence that he relates to the earth more wisely and caringly than humans, because they would have it rain only where they live and farm.

12 Yahweh was putting to Job an argument similar to the one Job had used to support his complaint that the wicked, not the righteous, prosper. In a tirade on the inadequacies of retribution for explaining affairs on earth, Job asks the friends if they have inquired of travelers from distant lands regarding cases that challenged their teaching of retribution (21:29-30). The implied negative answer indicates that they were speaking unwisely in applying that doctrine to Job's condition since they had not searched widely enough for evidence before formulating their dogmatic position. Yahweh is now responding to Job's challenge in kind by pointing out that he has not sought knowledge about the way the world operates by visiting the most distant recesses of the created world. Thus he lacks the perspective for substantiating his complaints that God fails to govern the world in justice. 
In the next vignette Yahweh asks intriguing questions about the origin of unique forms of moisture: dew, ice, and hoarfrost: "Has the rain a father; who has begotten the drops of dew; from whose womb did the ice come forth; who has given birth to the hoarfrost of heaven?" $(38: 28-30)^{13}$ In this question Yahweh uses terms for natural generation: father/has begotten, womb/has given birth. He is alluding to the fertility religion of the Canaanites, Israel's neighbors. Their two main deities were Baal, the storm god, and Asherah, the goddess of fertility. Baal had two daughters, Pidraya, "the daughter of mist," and Talaya, "the daughter of dew." The Canaanites believed that fertility was achieved by sexual congress of the god(s) and goddess (es). Yahweh, however, is countering that belief with these bizarre questions. His resourceful wisdom has led him to put in nature systems that produce water in a variety of forms independent of natural generation. This is especially the case with dew; overnight it appears mysterious, providing moisture to vast areas of Palestine, along the coast and into the highlands. It provides enough moisture for cedars, vines, and olive trees to flourish during the long, hot, rainless summer. ${ }^{14}$ Another anomaly is ice. Since water is a liquid, humans cannot grasp it with their hands, but when it turns to ice, it becomes as hard as stone, able to support great weight. At other times water appears almost mysteriously - at least to the ancients - as hoarfrost, making intriguing design with its crystals. That water appears in these various ways is a blow to Canaanite fertility religion.

The constellations, Pleiades, Orion, Bear, and Mazzaroth, are mentioned in this context for the ancients believed that they announced the coming of a season or a storm. Using chains and cords Yahweh guides the movement of the constellations far more closely than the other elements.

Yahweh continues by putting to Job imaginative questions about the clouds (38:34-38). He asks if Job can command the clouds to dispense rain where he lives or if he can order the lightning to flash across the sky? Of course, not! However, God has embedded in nature "an internally regulated system"15 and given it the wisdom ${ }^{16}$ to dispense a number of rain clouds to move across the

13 Vall, " "From Whose Womb Did the Ice Come Forth?' " 504-13.

14 Along Israel's Coastal Plain the number of nights of dew ranges from 200-250 in the north, averaging $1.2 \mathrm{in}$. annually; for the western slopes of the highlands the number of nights is from 100-180 (Efraim Orni and Elisha Efrat, Geography of Israel, $3^{\text {rd }}$ rev. ed. [Jerusalem: Israel Universities Press, 1973], 153, 155).

15 Habel ("Earth First," 75) speaks of "an internally regulated system within which each component of Earth has its locus and function in the system." Thus "Earth is not [regularly] governed by direct divine intervention."

16 Given the textual problems in v. 16 the identification of the recipient of wisdom is difficult to determine. Two frequently proposed options are the ibis and the cock (Clines, 
sky and pour out the rain they are carrying at the place the system has determined. In other words, God has embedded in the world a system that regulates the meteorological forces, i.e., wind, clouds, temperature, etc. so that they water a given region at a given time. Because these forces are always intermingling, the weather continually changes. On occasions the clouds pour out so much water that a large area of land becomes a sea of mud, ${ }^{17}$ rendering it impassable.

Since God has made the earth's ecology self-sustaining, God does not regularly set the time, place, or amount of water the clouds are to dispense. In fact, the constant variation of weather, daily and from year to year, is evidence that God has given these forces a measure of freedom. Nevertheless, their having freedom comes with a risk. There is the potential that a storm may become so powerful that its wind and rain cause extensive damage to property and humans or that it fails to dispense enough water, resulting in a drought that threatens the well-being of all animals. As a result of the freedom Yahweh has placed throughout the creation, earth has a dynamic, challenging environment, but one that is not risk-free.

\section{The Role of Freedom in the World Order}

In this speech Yahweh accentuates two themes: secure structures that support the earth and dynamic forces that maintain its environment to support a myriad of life forms. Yahweh begins by contrasting these two themes: he carefully built a secure foundation for the earth; then he brought forth the dynamic sea to be its primary occupant. God then proceeded to put in place various complex systems empowered by dynamic forces for maintaining earth's ecology. Because these forces are dynamic, each exercises a measure of freedom in carrying out its function. Consequently the world order is not carefree, ${ }^{18}$ risk-

Job $38-42,1050,1116)$ or the inward parts and the mind (NRSV). Despite this problem, God says that the clouds are numbered in wisdom in v. 37. Thus Yahweh is stressing that he has placed in earth's ecological system the wisdom to form rain clouds for watering the earth.

17 Based on the Mesopotamian account of Marduk's creating the earth, van Wolde renders this verse "when soil was poured into a mold, the clods stuck together." That is, clumps of dirt are poured from the heavenly jars and form soil on earth ("Dialogue between Job 28 and Job 38," 377).

18 LaCocque, “The Deconstruction of Job's Fundamentalism," 85. 
free, ${ }^{19}$ or conflict free. ${ }^{20}$ E.g., water, although it is absolutely essential for all life forms, may be very dangerous, even deadly, especially as a torrential rainstorm or as a strong current in a stream. Humans enjoy water immensely, finding great pleasure from playing with and in it. That pleasure, however, may quickly turn to tragedy when a person drowns. Gravity plays a critical role in earth's functioning. However, a person who falls may incur injury. Since God has provided elements, forces, and animals freedom, humans are continually faced with numerous hardships, including natural disasters, accidents, and conflicts. These hardships often inflict losses and injuries, resulting in suffering. Nevertheless, these challenges play a vital role in human development. In dealing with difficulties, a person has the opportunity to build a strong body, to develop virtues, and to enhance mental skills. But given human freedom, the results of coping with problems and dealing with suffering vary widely. One person develops skills for dealing with setbacks, gaining confidence, but another person becomes despondent and unproductive.

Yahweh's emphasis on the freedom that is present throughout the created order provides Job and the interlocutors a more nuanced perspective on the way the world functions. The presence of freedom in the created order undercuts an inflexible application of retribution as articulated by the interlocutor, for that doctrine has no mechanism for taking the freedom of nature or humans into account in interpreting conditions that occur in the world, either an individual's suffering or widespread devastation such as that wrought by a hurricane. Moreover, this new perspective provides Job a theological basis for the arguments he set forth against the viability of the doctrine of retribution as an explanation of injustice or inequity (Job 21). In other words, given the presence of freedom throughout the world order, it cannot be argued either that the suffering of the blameless is evidence that Yahweh's rule is unjust or that a person who is suffering is thereby guilty of wrongdoing.

Because the interlocutors never take into account the freedom that is ingrained in the created order, their arguments designed to motivate Job to repent of wrongdoing have been misleading. In fact, their counsel has tempted him to

19 Fretheim (God and World, 235) notes that "suffering can take place quite apart from sin and evil."

20 Yahweh makes a few references to conflicts between peoples $(38: 15,23 ; 39: 21-25$, 29-30). Although Yahweh does not address the issue of wars, it is important to note that he does not ignore it, since wars cause horrible suffering. Yahweh emphasizes that no battle is beyond his control, for in the heavenly storehouses he has available a stockpile of snow and hail as weapons. With them he can direct the course of any battle. Therefore, a war is no threat to his rule or his achieving his goals on earth. In general Yahweh has put in the world structure various checks to evil activities (LaCocque, "Deconstruction," 85). 
contrive repentance in order that his health and wealth might be restored. Had Job followed their counsel, he would have given evidence that he serves Yahweh for personal gain rather than for a relationship with Yahweh. Fortunately Job rejected their counsel. Conversely, Yahweh's portraits of the world show Job that he has erred in his bitter complaints against Yahweh's managing the world, especially in describing Yahweh's rule as capricious in overturning the social order of a region (12:13-25) and his accusing Yahweh with mocking the calamity of the blameless and with covering the eyes of judges so that the wicked are not held accountable for their foul deeds (9:22-24).

Thus Job exercised his freedom in rejecting their counsel. As a result Job becomes the hero of the drama and a model for those facing extreme hardship. An underlying theme of Job's interaction with Yahweh is to show that humans prize their freedom. Freedom energizes their lives. It makes possible a wide variety of dynamic experiences as the acquisition of new skills, imaginative undertakings, making discoveries, and the invention of an amazing product. ${ }^{21}$ In exercising their freedom humans experience exuberant joy.

From Yahweh's emphasis on freedom it may be inferred that he prizes his own freedom..$^{22}$ As an expression of his freedom he has limited his power by design. A key example of this self-limitation is his sharing responsibilities for the world's well-being with natural forces and with humans. ${ }^{23}$ Furthermore, Yahweh displays his freedom by interacting with the created order and humans in surprising ways. In fact, his acting in freedom is an expression of his sovereignty. ${ }^{24}$ Yahweh often relates to the world and its inhabitants in new, surprising ways. This is well attested throughout Scripture, from his appearing to Moses in a burning bush to his becoming Mary's baby.

Being sovereign, Yahweh is free to interact with the world and humans in ways that transcend human standards of justice - a reality that frees Yahweh from rules and conventions that humans devise to regulate people. ${ }^{25}$ By

21 Cf. Fretheim, "God in the Book of Job," 92.

22 Whybray ("Wisdom, Suffering, and the Wisdom of God in the Book of Job," 242-43) says, "The tone of these vignettes (about the wild animals) suggests that what Yahweh values above all else in his world is freedom."

23 Clines, “Job 38-42," 1095.

24 Scholnick (“The Meaning of (mišpat) in the Book of Job," 527) shows that Hebrew mišpat includes justice, moral rectitude, and divine sovereignty. The ruler has complete authority on the basis of his position. A ruler's ability to exercise freedom in a decision or an action is grounded on his sovereignty. As the Supreme Sovereign, Yahweh may require a subject to take on a task or deal with a situation out of the ordinary as he did in granting Satan permission to test Job.

25 Cf. Whybray, "Wisdom, Suffering," 242-43. 
gaining a more comprehensive perspective on the ways Yahweh has structured and interacts with the world, humans are able to construct a more nuanced understanding of God's relationship with the world and with them. This new perspective provides the upright a sound basis for maintaining confidence in Yahweh while coping with harsh setbacks and painful experiences. In other words, while the suffering of the blameless mocks the doctrine of retribution, it does not serve as evidence that Yahweh fails to govern the world order wisely and judiciously nor that God no longer cares for those dealing with hardship or suffering.

Given Job's freedom either to engage with Yahweh or reject his questioning, Yahweh did not expect his troubled servant to be quickly persuaded by his arguments. After Job briefly stated that he was not ready to withdraw his lawsuit (40:3-5), God delivered a second speech in which he spoke of the two premier animals that inhabit the wilderness: Behemoth and Leviathan (40:6-41:34). Accepting the insights God has presented in both speeches, Job retracts his lawsuit, the dominant symbol of his pride. Yahweh then authenticates Job's response by commissioning him to offer sacrifices on behalf of the interlocutors. His performing this role provides public evidence that Yahweh has restored Job and that his relationship with Yahweh has been strengthened. Having endured a season of suffering, Job is now more resourceful in encouraging and helping others, especially in their relationship with Yahweh.

\section{Implications for Today}

The rapid growth of earth's population in recent decades has resulted in the domestication of extensive areas of wilderness. The assault on the wilderness has been facilitated by human ingenuity in designing and building heavy-duty equipment for moving vast volumes of earth and for constructing huge edifices. In addition, nations and businesses have become engaged in extensive mining projects in the wilderness to gain access to its resources, often with little regard for a region's ecology. These changes have significantly altered the human attitude toward wild animals. No longer leaving them alone, people have hunted various species, especially those having commercial value. As a result, some species have become extinct and many more are endangered. Fortunately several conservation measures have been put into place to protect wilderness areas and the animals.

Another threat to earth's ecology is the continuous growth of urban centers. Not only is land covered with concrete, these centers place a heavy demand on earth's resources. Adding to that demand is the increasing desire of the af- 
fluent for lavish goods. Seeking to profit from this demand, several businesses are taking materials from wilderness areas.

These challenges to earth's environment have been driven by the human belief that earth's resources exist for their exploitation. This attitude comes from their hubris. Scripture discloses that from antiquity human arrogance has been a major barrier between them and God as well as between clans and nations. Yahweh counters this attitude in his descriptions of the ways he has structured the systems that nurture earth's environment, enabling it to support myriads of plants and animals. The dynamic character of the forces in these systems, especially those that make up daily weather patterns, are evidence that Yahweh prizes variety and novelty within a secure structure. In the animal vignettes Yahweh emphasizes his care for the wilderness and the wild animals. Rather than dominating the animals, he cares for them. That care includes his protecting their freedom, especially from human domination, as is vividly set out in the vignettes of the wild ass and the wild ox. Yahweh has given these powerful animals a disposition that prevents humans from domesticating them and making them serve in the fields.

Yahweh's description of the world provides insights that provide a guide for humans to relate to the earth, not as dominators, but as custodians. ${ }^{26}$ In taking on this role they will use their intellectual skills in devising ways to promote earth's ecology so that it will continue to support an enormous population. ${ }^{27}$ Another challenge that needs to be addressed is discovering ways for the vast urban centers to become ecologically friendly. By becoming custodians of the earth, humans will preserve their own freedom from being usurped by powerful forces such as technology, forces that are producing radical changes in society, changes that threaten their freedom. ${ }^{28}$

26 This view is argued well by Habel, "Is the Wild Ox Willing to Serve You," 179-89. He says, "The principle of mutual custodianship states that Earth is a balanced and diverse domain in which responsible custodians can function as partners, rather than rulers, to sustain a balanced and diverse Earth community" (179).

27 Invigorating the present discussion of leading humans to relate to earth as custodians is the work of the Earth Bible Team. Its members, include scholars from throughout the globe, including both hemispheres, are re-reading Scripture from an ecojustice perspective. Their goal is to let earth's voice be heard. Results of their studies are being published in the series The Earth Bible by Sheffield Academic Press.

28 Patrick, "Divine Creative Power," 115. 


\section{Bibliography}

Alter, Robert. The Wisdom Books: Job, Proverbs, and Ecclesiastes. New York: W. W. Norton \& Company, 2010.

Balentine, Samuel E. "What Are Human Beings, That You Make So Much of Them?" Divine Disclosure from the Whirlwind: "Look at Behemoth," In God in the Fray; A Tribute to Walter Brueggemann, edited by Tod Linafelt and Timothy K. Beal, pages 259-178. Minneapolis: Fortress, 1998.

Brenner, Athalya. “God's Answer to Job.” Vetus Testamentum 31 (1981): 129-137.

Brown, W. P. Character in Crisis: A Fresh Approach to the Wisdom Literature of the Old Testament (Grand Rapids: Eerdmans, 1996): 89-119.

Clines, David. J.A. Job 1-20. Word Biblical Commentary 17. Dallas: Word Books, 1989. . Job 38-42. Word Biblical Commentary 18B. Nashville: Thomas Nelson, 2011.

Dailey, T. F. “Theophanic bluster: Job and the wind of change." Studies in Religion / Sciences religieuses 22 (1993): 187-195.

Dick, Michael B. “The Neo-Assyrian Royal Lion Hunt and Yahweh's Answer to Job." Journal of Biblical Literature 126 (2006): 243-270.

Fox, Michael V. "Job 38 and God's Rhetoric." In The Book of Job and Ricoeur's Hermeneutics, edited by John Dominic Crossan. Semeia 19:53-61. Chico, CA: Scholars Press, 1981.

Fretheim, Terence E. "God in the Book of Job." Currents in Theology And Mission 26 (1999): 2:85-93.

God and World in the Old Testament: A Relational Theology of Creation. Nashville: Abingdon Press, 2005.

Habel, Norman C. "Earth First: Inverse Cosmology in Job." In The Earth Story in Wisdom Traditions. edited by Normal C. Habel and Shirley Wurst, pages 65-77. Sheffield: Academic Press, 2001.

" "Is the Wild Ox Willing to Serve You?' Challenging the Mandate to Dominate." In The Earth Story in Wisdom Traditions. edited by Normal C. Habel and Shirley Wurst, pages 179-189. Sheffield: Academic Press, 2001.

Janzen, Gerald. Job. Interpretation. Atlanta: John Knox, 1985.

Keel, Othmar. Jahwes Entgegnung an Ijob. Eine Deutung von Ijob 38-41 vor dem Hintergrund der zeitgenössischen Bildkunst. Forschungen zur Religion und Literatur des Alten und Neuen Testaments 121. Göttingen: Vandenhoeck \& Ruprecht, 1978.

LaCoque, André. “The Deconstruction of Job's Fundamentalism.” Journal of Biblical Literature 126 (2007): 83-97.

Lévêque, Jean. "L'Interpretation des discours de Yhwh (Job 38,1-42,6)." In The Book of Job, edited by W. A. M. Beuken, pages 203-222. Leuven: University Press, 1994.

Lockwood, Peter. "God's Speech from the Whirlwind: the Transformation of Job through the Renewal of His Mind." Lutheran Theological Journal 45 (2011): $167-182$. 
Luc, Alex. "Storm and the Message of Job." Journal for the Study of the Old Testament 87 (2000): 111-123.

Mettinger, Tryggve. N. D. “The Enigma of Job.” Journal of Northwest Semitic Languages 23 (1997): 1-19.

Miller, J. E. "Structure and Meaning of the Animal Discourse in the Theophany of Job (38, 39-39,30)." Zeitschrift für die alttestamentliche Wissenschaft 103 (1991): 421.

Newsom, Carol A. The Book of Job. Oxford: University Press, 2003. . "The Book of Job." in The New Interpreter's Bible, vol. 4. pages 317-637. Nashville: Abingdon Press, 1994.

O'Connor, Kathleen M. "Wild, Raging Creativity: the Scene in the Whirlwind (Job 3841)." In A God So Near: Essays on Old Testament Theology in Honor of Patrickd. Miller, edited by Brent A. Strawn and Nancy R. Bowen, pages 171-79. Winona Lake, IN: Eisenbrauns, 2003.

Patrick, Dale. "Divine Creative Power and the Decentering of Creation: the Subtext of the Lord's Addresses to Job." In The Earth Story in Wisdom Traditions. edited by Norman C. Habel and Shirley Wurst, pages 103-15. Sheffield: Academic Press, 2001.

Scholnick, Sylvia Huberman. “The Meaning of mišpat in the Book of Job." Journal of Biblical Literature 101 (1982): 521-529. DOI: http://dx.doi.org/10.2307/3260896. . "Poetry in the Court Room: Job 38-41." In Directions in Biblical Hebrew Poetry, edited by Elaine R. Follis, pages 185-204. Journal for the Study of the Old Testament, Supplement Series 40. Sheffield: JSOT Press, 1987.

Schmidt, N. F., and P. J. Nel. “The Rhetoric of the Theophany of Job." Old Testament Essays 16 (2003): 79-95.

Steinmann, A. E. “The Structure and Message of the Book of Job." Vetus Testamentum 46 (1996): 85-100.

Vall, G. " 'From Whose Womb Did the Ice Come Forth?' Procreation Images in Job 38:28-29." Catholic Biblical Quarterly 57 (1995): 504-513.

Wilson, Lindsay. "Job 38-39 and Biblical Theology." The Reformed Theological Review 62 (2003): 121-138.

Wolde, Ellen van. “Towards an 'Integrated Approach' in Biblical Studies, Illustrated with a Dialogue Between Job 28 and Job 38." In Congress Volume Leiden 2004, edited by André Lemaire, pages 355-380. Supplements to Vetus Testamentum 109. Leiden: Brill, 2006.

Whybray, R. N. "Wisdom, Suffering and the Freedom of God in the Book of Job (Job 38-41)." In In Search of True Wisdom, edited by Edward Ball, pages 231-245. Journal for the Study of the Old Testament Supplement Series 300. Sheffield: Sheffield Academic Press, 1999. 